\title{
Erratum to cerebrotendinous xanthomatosis with peripheral neuropathy: a clinical and neurophysiological study in Chinese population
}

\author{
Editorial office \\ Annals of Translational Medicine \\ Correspondence to: Editorial office. Annals of Translational Medicine. Email: editor@atmjournal.org.
}

doi: 10.21037/atm-2021-2

View this article at: http://dx.doi.org/10.21037/atm-2021-2

Erratum to: Ann Transl Med 2020;8:1372

In the article that appeared on Page 1372, Vol 8, No 21 (November 2020) Issue of the Annals of Translational Medicine (1), in the published abstract, "Three novel mutations including c.1055C >A; c.432T>G; c.472T>G were identified in CYP27A1 and predicted to be pathogenic" "Three novel likely pathogenic mutations including c.1055C $>\mathrm{A}$; c.432T $>\mathrm{G}$; c.472T $>\mathrm{G}$ were identified in CYP27A1", and in the conclusion part, "Three novel mutations c.1055C>A, c.432T>G, c.472T>G are detected and predicted pathogenic", the mutation "c.472T>G" should be "c.472C>T".

Click here to view the updated version of the article.

Open Access Statement: This is an Open Access article distributed in accordance with the Creative Commons AttributionNonCommercial-NoDerivs 4.0 International License (CC BY-NC-ND 4.0), which permits the non-commercial replication and distribution of the article with the strict proviso that no changes or edits are made and the original work is properly cited (including links to both the formal publication through the relevant DOI and the license). See: https://creativecommons.org/ licenses/by-nc-nd/4.0/.

\section{References}

1. Zhang S, Li W, Zheng R, et al. Cerebrotendinous xanthomatosis with peripheral neuropathy: a clinical and neurophysiological study in Chinese population. Ann Transl Med 2020;8:1372.

Cite this article as: Editorial office. Erratum to cerebrotendinous xanthomatosis with peripheral neuropathy: a clinical and neurophysiological study in Chinese population. Ann Transl Med 2021;9(5):442. doi: 10.21037/atm-2021-2 